\title{
Proposal for the Use of Soft Magnetic Material with Negative Uniaxial Magnetocrystalline Anisotropy as an SUL to Suppress both WATE and Spike Noise
}

\author{
A. Hashimoto, S. Saito, and M. Takahashi* \\ Department of Electronic Engineering, Tohoku University, 6-6-05, Aza-Aoba, Aramaki, Sendai 980-8579, Japan \\ *New Industry Creation Hatchery Center, Tohoku University, 6-6-10, Aza-Aoba, Aramaki, Sendai 980-8579, Japan
}

\begin{abstract}
Suppression of spike noise and wide adjacent track erasure (WATE) are important technical issues for perpendicular recording media (PRM) with a soft magnetic underlayer (SUL). To solve these problems simultaneously, we propose in this paper a new type of SUL with negative uniaxial perpendicular magnetic anisotropy $\left(K_{\mathrm{u}_{\perp}}\right)$ induced by material with negative uniaxial magnetocrystalline anisotropy $\left(K_{\mathrm{u}}\right.$ grain). For the proposed SUL, it can be expected that (1) WATE will be suppressed due to a wide distribution of magnetic flux under the return yoke, and that (2) spike noise will be eliminated due to the formation of a Neel wall instead of a Bloch wall. We selected hcp-CoIr as a negative $K_{\mathrm{u}}$ grain material and fabricated $c$-plane-oriented CoIr film by sputtering. $K_{\mathrm{u}}$ grain of $c$-plane-oriented CoIr film had a minimum value of $-6 \times 10^{6} \mathrm{erg} / \mathrm{cm}^{3}$ (saturation magnetization, $M_{\mathrm{s}}=920 \mathrm{emu} / \mathrm{cm}^{3}$ ) at an Ir content of 22 at.\%. In PRM using $c$-plane-oriented CoIr films as SULs, WATE could be suppressed compared with the PRM using amorphous CoZrNb as SUL. And from evaluation of envelopes for PRM using $c$-plane-oriented CoIr films as SULs, it was found that spike noise could not be clearly observed with a CoIr thickness below the calculated critical thickness of Neel wall formation.
\end{abstract}

Key words: negative uniaxial magnetocrystalline anisotropy energy, spike noise, wide adjacent track erasure, Neel wall, soft magnetic underlayer

\section{負の一軸結晶磁気異方性をもつ軟磁性材料を用いた裏打ち膜の提案 一 WATE およびスパイクノイズの同時抑制のために —}

\author{
橋本 篤志，斉藤 伸，高橋 研* \\ 東北大学大学院工学研究科電子工学専攻, 仙台市青葉区荒巻字青葉 6-6-05 (广 980-8579) \\ *東北大学未来科学技術共同研究センター, 仙台市青葉区荒巻字青葉 6-6-10（广980-8579）
}

\section{1. はじめに}

垂直磁気記録媒体では，媒体側にヘッド系磁気回路の一部とし て機能する軟磁性裏打ち膜 (SUL: Soft Magnetic Underlayer, $d \mathrm{suL} \geqq 50 \mathrm{~nm}$ ）を設ける必要があり，このことが面内媒体では問 題とならなかった様々な課題をもたらす．特に時間軸上で信号出 力とは無関係に摇らぐスパイクノイズの発生や, オフトラック方 向への数 $\mu \mathrm{m}$ にわたる記録情報の消去 (WATE: Wide Adjacent Track Erasure）は，情報記録デバイスとしての根幹に関わるビッ トエラーレートを劣化させるため，いずれも抑制することが技術 課題である.これまで，スパイクノイズを抑制するためには，反 強磁性層 (AFL: Antiferromagnetic Layer) との積層による単磁 区化 SUL1)-3) が，WATE の抑制のためには，非磁性層 (NML: NonMagnetic Layer) を軟磁性層で挟み込み上下の軟磁性層磁化 を反平行配列させた $\mathrm{SUL}^{4)}$ が，それぞれ有効であると報告されて きた. さらに近年では，これらの層構成を組み合わせた $\mathrm{AFL} /$ 軟 磁性層/ NML/ 軟磁生層なるSULによりスパイクノイズとWATE のいずれも抑制させうることが報告されている5).しかしながらこ の手法では，SUL作製のための層数が増すことや，一方向磁気異 方性誘導のために加熱ならびに磁界中冷却プロセスが必須とな り，プロセスが複雑になる。一方，媒体を量産する観点か らはより簡略なプロセスが望まれている，そこで本報では,
できるだけ簡素な層構成およびプロセスによってスパイクノイズ およびWATE を同時に抑制できる新規 SUL の材料設計指針を検 討し，実際に実験によりその基礎特性を評価したので報告する.

\section{2. 裏打ち層の材料設計}

\section{1 設計指針}

まず，スパイクノイズの抑制法について考える. AFL との積層 SUL がスパイクノイズの抑制に効果的であることは前述したが, この手法を用いても SUL 膜厚を厚くしすぎるとスパイクノイズ が発生する5)。この理由として筆者らは, SULが厚い場合にはAFL による磁化のピンニングが有効に働かず，AFL/ SULの積層界面 から離れた SUL の一部に, 膜面垂直方向に磁化が立ち上がって回 転する $180^{\circ}$ 磁壁が形成されてしまうためであると考えている ${ }^{6)}$. 一方, NML を挿入し, 上下層の磁化を反平行配列させた SUL で は, 残留磁化状態で多磁区構造をとるにもかかわ加ず, その磁壁 に起因したスパイクノイズはほとんど観測されない5).この理由は, SULの上層および下層の磁化閒の反強磁性的結合が強いため, 上 下層の磁化が磁壁部分でも反平行配列を維持したまま面内で回転 する $180^{\circ}$ 磁壁対 7) を形成しているためであると考えられる. これ ら 2 つ事例を考え合わせると，スパイクノイズの抑制のために は，単磁区化を図ることが最も好ましいが，多磁区状態であって 
もその境界の磁壁の構造を, 垂直方向への漏孔磁束を低減できる 面内回転型にすることが肝要である.

次にWATEの抑制法について考察する. WATEは, その消去範 囲を考慮すると, リターンヨークへの環流磁束がヨーク端部に集 中することにより, 記録層の磁化が反転させられる現象と考えら れ，記録へッド，記録層，SULの全てが関わる現象である. した がってWATE の抑制には, ヘッド側，媒体側の各々での対応策が 考えられるが，SULの磁気特性を制御することによる対応策とし て筆者らは, SULの垂直方向の磁化率 $\left(\chi_{\perp}\right)$ を低減させてリター ンヨーク部での環流磁束を分散させる手法を報告している ${ }^{8)}$. さら に層構成およびプロセスの簡素化をも考慮すると, 上述した面内 回転型磁壁の形成および $\chi_{\perp}$ の低減を，1層の磁生層に担わせるこ とができれば利点が多い.これらの点を考慮して我々は, SULに 負の垂直磁気異方性エネルギー $\left(K_{\mathrm{u} \perp}\right)$ を具備させる手法を提案す る.ここで $K_{\mathrm{u}_{\perp}}$ とは, 反磁界に起因する自己エネルギーを除いた, SUL の有する膜面垂直方向の一軸磁気異方性エネルギーを指す. 負の $K_{u_{\perp}}$ 導入による $\chi_{\perp}$ の低減効果については文献 8 で報告して いるので, 次項では, SUL 中に形成される磁壁構造と $K_{\mathrm{u}}$ との相 関について議論する.

\section{2 ネール磁壁の安定形成}

$K_{\mathrm{u} \perp}$ が付加された SULに $180^{\circ}$ 磁壁が 1 枚形成された場合, 磁壁 エネルギ一密度（の）は，それぞれ異方性エネルギ一，交換結合エ ネルギー, 静磁気エネルギーの和として, 以下のように表すこと ができる.

$$
\begin{aligned}
& \sigma_{\mathrm{N}}=\frac{d_{\text {wall }} K_{\mathrm{u}}^{\mathrm{inp}}}{2}+\frac{\pi^{2} A}{d_{\text {wall }}}+\frac{d_{\text {wall }} d_{\text {SUL }} \pi M_{\mathrm{s}}^{2}}{d_{\text {wall }}+d_{\text {SUL }}} \\
& \sigma_{\mathrm{B}}=\frac{d_{\text {wall }}\left(K_{\mathrm{u}}^{\mathrm{inp}}-K_{\mathrm{u} \perp}\right)}{2}+\frac{\pi^{2} A}{d_{\text {wall }}}+\frac{d_{\text {wall }}{ }^{2} \pi M_{\mathrm{s}}^{2}}{d_{\text {wall }}+d_{\mathrm{SUL}}}
\end{aligned}
$$

ここで $\sigma_{\mathrm{N}}, \sigma_{\mathrm{B}}$ はそれぞれネール型, およびブロッホ型構造をとっ た際の磁壁エネルギ一密度を表し，dsuLはSUL膜厚，dwall は磁壁 厚さ， $K_{\mathrm{u}}^{\mathrm{inp}}$ は SUL 膜面内の一軸磁気異方性エネルギ一， $A$ は交 換スティフネス定数である. $K_{\mathrm{u} \perp}$ は式 (2) のみに現れることに注意

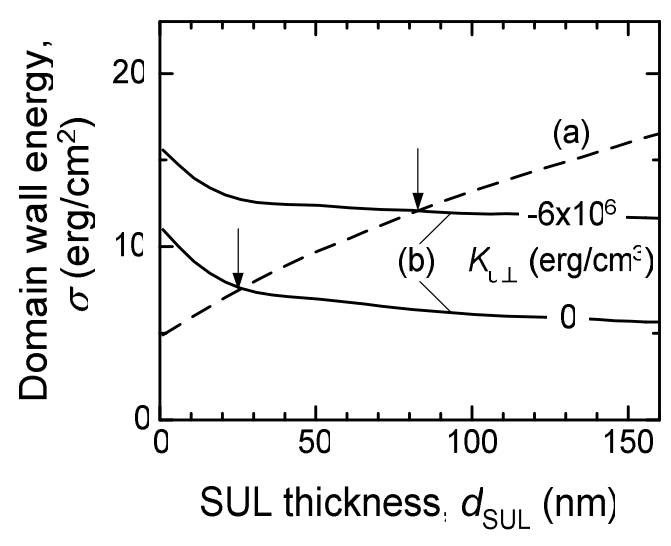

Fig. 1 Thickness dependence of the SUL on the energy density of domain walls of (a) Neel type (broken line) and (b) Bloch type (solid lines) for films with negative $K_{u_{\perp}}$. The allows indicate the maximum SUL thickness of Neel wall formation, $d_{\text {crt }}$, in the cases of $K_{\mathrm{u}_{\perp}}=0$ and $-6 \times 10^{6}$ $\mathrm{erg} / \mathrm{cm}^{3}$.

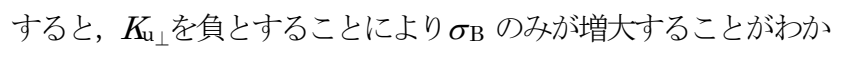
る. Fig. 1 には, SUL 膜厚に対する (a) $\sigma \mathrm{N}$, および (b) $\sigma \mathrm{B}$ の計算 結果の一例を示寸．数值計算を行うにあたっては， $K_{u \perp}$ には 0 $\mathrm{erg} / \mathrm{cm}^{3}$ もしくは- $6 \times 10^{6} \mathrm{erg} / \mathrm{cm}^{3}$ を， $M_{\mathrm{s}}, K_{\mathrm{u}}^{\mathrm{inp}}, A$ には軟磁生材 料として一般的な物性值 $\left(M_{\mathrm{s}}: 1000 \mathrm{emu} / \mathrm{cm}^{3}, K_{\mathrm{u}}^{\mathrm{inp}:} 5 \times 10^{3}\right.$ $\left.\mathrm{erg} / \mathrm{cm}^{3}, A: 1.0 \times 10^{-6} \mathrm{erg} / \mathrm{cm}\right)$ を用いた. $\sigma_{\mathrm{N}}, \sigma_{\mathrm{B}}$ の大小関係よ り, SUL の膜厚が薄い領域ではネール磁壁が, 厚い領域ではブ ロッ木磁壁が， $K_{\mathrm{u} \perp}$ の值に関わらず安定であることがわかる， $\sigma_{\mathrm{B}}=$ $\sigma_{\mathrm{N}}$ の交点により定められる, ネール磁壁が形成される最大臨界膜

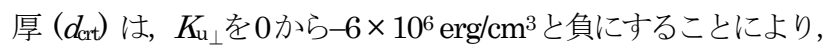
$25 \mathrm{~nm}$ から $86 \mathrm{~nm}$ まで増大寸る. Fig. 2 には, $M_{\mathrm{s}}, K_{\mathrm{u}}^{\mathrm{inp}}, A$ の值 を Fig. 1 に示した計算と同様の一定値とし, $K_{u \perp}$ のみを種々に変化

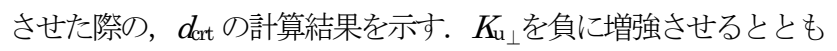
に $d_{\text {cat }}$ は増加し， $K_{u \perp}$ を-3 $310^{6} \mathrm{erg} / \mathrm{cm}^{3}$ 以下とすることにより $d_{\text {cat }}$ は $50 \mathrm{~nm}$ 以上となる. このことは, $10^{6} \mathrm{erg} / \mathrm{cm}^{3}$ オーダーの負 の $K_{u_{\perp}}$ を付与寸ることにより, SUL の実用膜厚範用でもブロッホ 磁壁に代わってネール磁壁を安定形成できることを示している.

\section{3. 負の垂直磁気異方性をもつ SUL の実現}

\section{$3.1 c$ 面配向 Colr 膜の作製およびその磁気物性值}

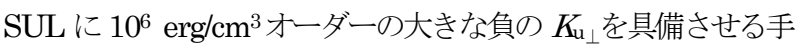
段としては, 結晶磁気異方性の利用が有効である. 寸なわち, 一 軸結晶磁気異方性エネルギー (Ku Kurain $^{\text {gra }}$ が負である六方晶相や正方 晶相を $c$ 面配向させれば $K_{\mathrm{u}_{\perp}}=K_{\mathrm{u}}$ grain となり, 提案中の SUL を実 現できる可能性がある. 室温近傍で負の $K_{\mathrm{u}}$ grain を有する材料とし ては, $\alpha^{\prime}-\mathrm{FeC}{ }^{9}$, dhcp-CoFe ${ }^{10)}, \mathrm{NiAs}$ 型-MnSb ${ }^{11}$, hcp-CoIr ${ }^{12)}$ 等が知られている.この中で本実験では, 比較的飽和磁化が高く, 広い組成範囲で不規則構造の平衡相として存在する材料という観 点から, hcp-CoIr を選択した. 文献 12 によると, $\mathrm{MgO}$ 基板を 用いてエピタキシャル成長させた (100) 面配向 Co $80 I_{20}$ 膜の一軸 結晶磁気異方性エネルギー (文献 12 中の $K_{1}$ と $K_{2}$ の和に相当) は $-6 \times 10^{6} \mathrm{erg} / \mathrm{cm}^{3}$ 程度である.

以下, 本項で議論する CoIr 薄膜の作製法について述べる. CoIr 膜は dc マグネトロンスパッタリング法を用いCo ターゲットと Ir ターゲットとの 2 元同時放電によって結晶化ガラス基板上に室温 成膜した. 成膜チャンバの到達真空度は $5 \times 10^{-6} \mathrm{~Pa}$ であり, 成

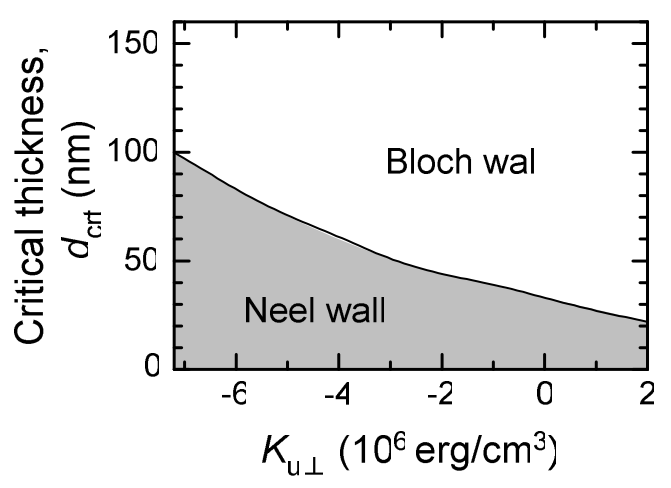

Fig. 2 Change in the calculated critical thickness as a function of $K_{\mathrm{u}}$. 
膜時の $\mathrm{Ar}$ ガス圧は0.6 Pa とした. 膜の組成は, 各々のターゲッ トへの投入電力を変化させて調整し, 蛍光 $\mathrm{X}$ 線法によって定量 評価した. CoIr 膜の膜厚は $50 \mathrm{~nm}$ 一定とした.

まず, CoIr 膜の $c$ 面配向化の検討を行った．Fig. 3 には，下地 層として Ti(7 nm)/ Ru(3 nm) を用いた CoIr 膜の in-plane XRD プロファイルを, 試料の Ir 濃度 $\left(C_{\mathrm{rr}}\right)$ 毎に示す.すべての薄膜に おいて hcp-(100) 面およびhcp-(110) 面に起因する回折線のみが 良好に観測され，回折角 $2 \theta_{\chi}$ は Ir 濃度の増加に対応して低角側に

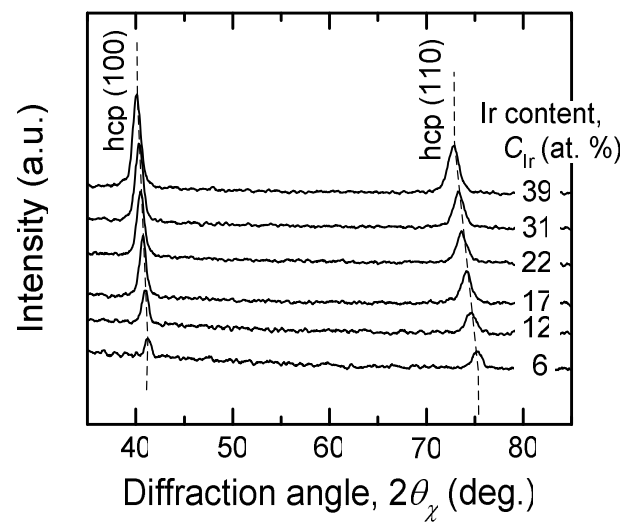

Fig. 3 In-plane XRD profiles for CoIr films using Ti/ Ru underlayers with various Ir contents.

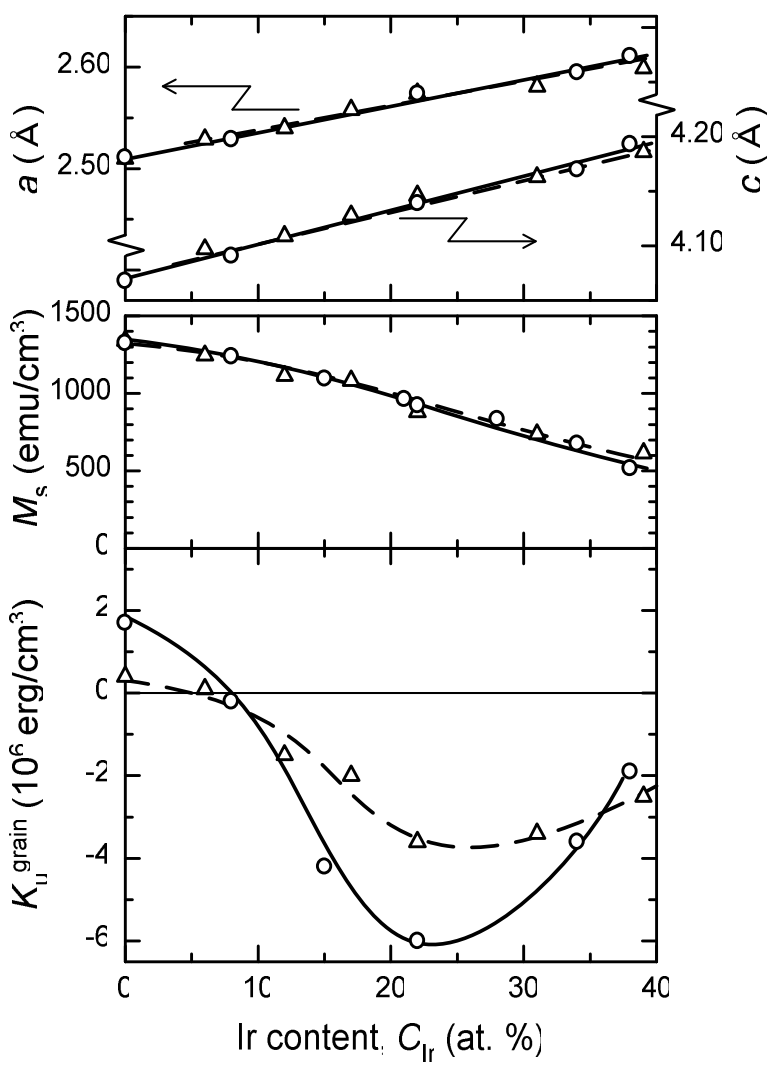

Fig. 4 Change in (top) lattice constants, a, $c$, (middle) $M_{\mathrm{s}}$ and (bottom) $K_{\mathrm{u}^{\mathrm{g}}}$ rain as a function of the Ir content for $c$-plane-oriented CoIr films using (circle) $\mathrm{Ti} / \mathrm{Ru}$ and (triangle) $\mathrm{Ta} / \mathrm{Pt} / \mathrm{Ru}$ underlayers, respectively.
シフトしている.このことから作製された CoIr 薄膜は，いずれの Crにおいても良好に $c$ 面配向していることがわかる. 尚, 下地の 層構成としては，他にも $\mathrm{Ta}(5 \mathrm{~nm}) / \mathrm{Pt}(6 \mathrm{~nm}), \mathrm{Ta}(10 \mathrm{~nm}) / \mathrm{Pt}(10$ $\mathrm{nm}) / \mathrm{Ru}(10 \mathrm{~nm})$ について検討しており, その上に成長する CoIr 薄膜が $c$ 面配向することを確認した. Fig. 4 上段にはin-plane お よび out-of-plane XRD プロファイルの回折角から導出した $c$ 面 配向 CoIr 結晶粒の格子定数 $a, c$ の $C_{\mathrm{r}}$ に対する変化を示寸. 図中 $\triangle$ は Ti/ Ru 下地層を, Oは Ta/ Pt/ Ru 下地層を用いて作製した CoIr 膜の結果である. $a, c$ は, 下地層の種類によらず, $C_{\mathrm{rr}}$ を増加 させるにつれ直線的に増加しており, 今回検討した $G_{\mathrm{r}}$ の範囲では, Ir は六方晶相内に固溶していることが確認できる.

次に $c$ 面配向 CoIr 膜の磁気物性值を評価した. Fig. 4 には $G_{\mathrm{r}}$ に対する $c$ 面配向 CoIr 膜の飽和磁化 $\left(M_{\mathrm{s}}\right.$; 中段), ならびに一軸結 晶磁気異方性エネルギー ( $K_{\mathrm{u}}^{\text {grain }}$;下段 $)$ を示す. ここで $K_{\mathrm{u}}^{\text {grain }}$ は, 試料の実効的な異方性の大きさによっては必ずしも厳密ではない が, 垂直磁気トルク曲線の $2 \theta$ 成分の磁界無限大漸近值を求め, 反 磁界エネルギー分を補正することにより求めた ${ }^{13)}$. $M_{\mathrm{s}}$ は下地層に 依存せず, $G$ rを 0 から 39 at. \%まで増加させると, $1350 \mathrm{emu} / \mathrm{cm}^{3}$ から $700 \mathrm{emu} / \mathrm{cm}^{3}$ まで単調に減少した. 一方, $K_{\mathrm{u}}$ grain については $C_{\mathrm{r}}=7$ at. \%付近で符号が正から負に変わり， $C_{\mathrm{r}}=22$ at. \%で極 小をとる傾向が認められる. ただしその極小值は下地層に依存し て異なり, Ti/ $\mathrm{Ru}$ 下地層では極小值は-3 $310^{6} \mathrm{erg} / \mathrm{cm}^{3}$ を示し, $\mathrm{Ta} / \mathrm{Pt} / \mathrm{Ru}$ 下地層ではー6 $\times 10^{6} \mathrm{erg} / \mathrm{cm}^{3}$ を示した. 以上のように $c$ 面配向させた CoIr 薄膜の $K_{\mathrm{u}}$ grain は, 下地層によって絶対值が多 少変化するものの, $C_{\mathrm{r}}=20$ at. \%付近で $10^{6} \mathrm{erg} / \mathrm{cm}^{3}$ オーダーの大 きな負の值を有することが確かめられた. 尚, $c$ 面配向 hcp-Co 基 材料の結晶磁気異方性エネルギーの大きさについては, $\mathrm{CoPt}$ 系材 料でも議論されているように 14) 下地材料や下地の成膜条件に依 存して変化することが知られつつあり, 起源が解明されれば, CoIr

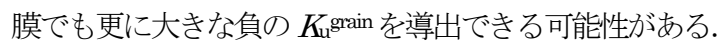

\section{$3.2 c$ 面配向 Colr 薄膜の軟磁気特性}

SULは, 記録時にヘッド系磁気回路としての機能を担うために, 膜面内方向では軟磁気的に振る舞うことが求められる. $c$ 面配向 CoIr 薄膜は, 対称性の高い $c$ 面を配向させた結晶粒を 2 次元ラン ダム配向させた集合組織を有する. したがって本SULは, 面内方 向ではランダム配向組織をもちつつも個々の結晶粒の面内方向の 結晶磁気異方性が小さいために局所的な磁気異方性分散が抑え られ，軟磁性化できることが期待される.

Fig. 5 には, 膜面内方向に誘導される一軸磁気異方性エ ネルギー $\left(K_{\mathrm{u}} \mathrm{inp}\right)$ を減少させることを意図してボロン元素 を添加した, CoIrB 薄膜の磁化容易軸方向（E. A.), 困難軸 方向 (H. A.) の保磁力 $\left(H_{\mathrm{c}}\right)$, ならびに $M_{\mathrm{s}}, K_{\mathrm{u}}$ grain の薄膜 中のボロン濃度 $\left(C_{\mathrm{B}}\right)$ に対する変化を示す.ここで, $\mathrm{CoIrB}$ 薄膜は, Co ターゲット, Ir ターゲット, CoB ターゲット を自公転させながら，三元同時放電させて作製している。 薄膜の組成は, Co:Ir の組成比を 78:22 で一定とし, CoIr: $\mathrm{B}$ の組成比のみを変化させるように各ターゲットへの投入 パワーを調整した．図中には参考のため， $C_{\mathrm{B}}=0,18$ at.\% の $\mathrm{CoIrB}$ 膜における磁化曲線を挿入困にて示す. E. A. は, 
成膜時のカソードからの漏れ磁界方向に対応しており, ディスク径方向からほぼ 60 70 度の方向であった. ボロン を添加しない場合, E. A. 方向, H. A. 方向の磁化曲線は大 きく異なり，例えば $H_{\mathrm{c}}$ はそれぞれ $80 \mathrm{Oe}, 20 \mathrm{Oe}$ であるこ

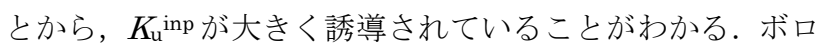
ンを添加すると, H. A. 方向の $H_{\mathrm{c}}\left(H_{\mathrm{c}}^{\mathrm{HA}}\right)$ はほとんど変化 せずに, E. A.方向の $H_{\mathrm{c}}\left(H_{\mathrm{c}}^{\mathrm{EA}}\right)$ が減少し， $C_{\mathrm{B}}$ を 18 at. \%ま で増加させると, $H_{\mathrm{c}} \mathrm{HA}$ と $H_{\mathrm{c}} \mathrm{EA}$ がほぼ一致した。このよう

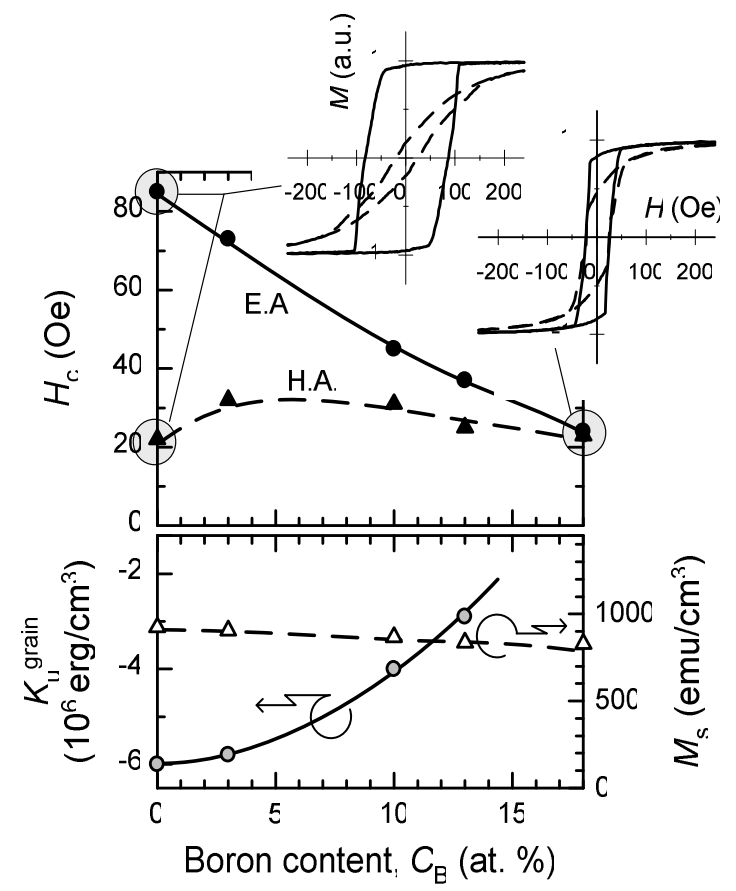

Fig. 5 (Top) Coercivity measured in the easy magnetization direction, $H_{\mathrm{c}} \mathrm{EA}$, and the hard magnetization direction, $H_{\mathrm{c}}{ }^{\mathrm{HA}}$, in the film plane, (bottom) $K_{\mathrm{u}}$ grain and $M_{\mathrm{s}}$ for $c$-plane-oriented $\left(\mathrm{Co}_{78} \mathrm{Ir}_{22}\right)_{100-\mathrm{x}} \mathrm{B}_{\mathrm{x}}$ films as a function of the $\mathrm{B}$ content. The inset shows the $M-H$ loops of the $\mathrm{Co}_{78} \mathrm{Ir}_{22}$ and $\left(\mathrm{Co}_{78} \operatorname{Ir}_{22}\right)_{82} \mathrm{~B}_{18}$ films, respectively.

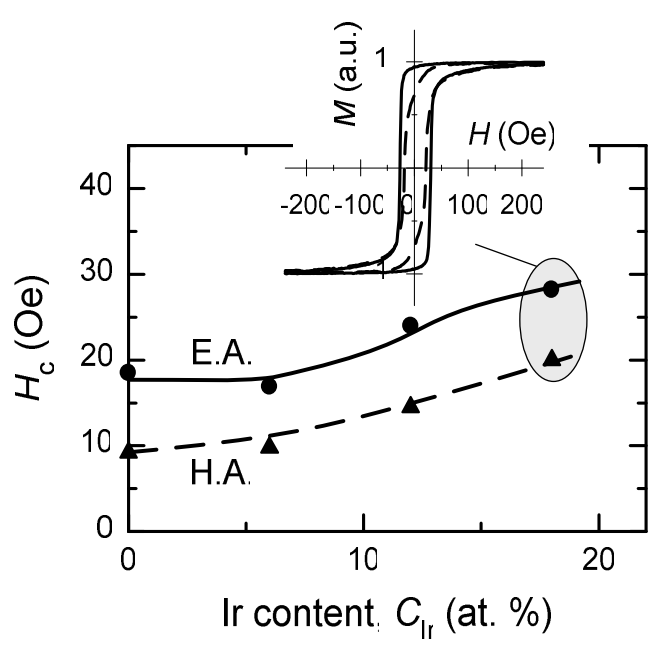

Fig. 6 Coercivity measured in the easy magnetization direction, $H_{\mathrm{c}}^{\mathrm{EA}}$, and the hard magnetization direction, $H_{\mathrm{c}}{ }^{\mathrm{HA}}$, in the film plane for $c$-plane-oriented CoIr films as a function of the Ir content. The inset shows the $M-H$ loops of the $\mathrm{Co}_{82} \mathrm{Ir}_{18}$ film.
にボロン添加は $K_{\mathrm{u}}^{\mathrm{inp}}$ を抑制する効果があり軟磁性化に有 効であることがわかったが，Fig. 5 下図に示すように， $K_{\mathrm{u}}$ grain の絶対值を低下させてしまうため, 注意を要する.

尚, $\mathrm{CoIrB}$ 膜の XRD プロファイルによると, ボロン添加 量に応じ回折線強度の減少が認められたが, いずれのボロ ン添加量の試料でも, $c$ 面以外の結晶配向を示す回折線は 観測されなかった。

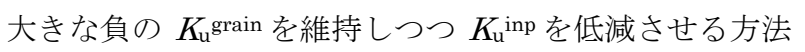
を模索し，異なるマグネトロンカソードでのスパッタリン グによる $c$ 面配向 CoIr 薄膜の作製を試みた，以降で議論す る CoIr 薄膜は, CoIr 合金ターゲットを用い, プレーナ配置 式静止カソードからのスパッタリングにより作製した. Fig. 6 には, Co, Co95 Ir5, Co90 Ir $\operatorname{Ir}_{10}, \mathrm{Co}_{85} \operatorname{Ir}_{15}$ (at.\%)の合金ター ゲットを用いて作製した $c$ 面配向 CoIr 膜における, 膜面内 の $H_{\mathrm{c}}^{\mathrm{EA}}$ および $H_{\mathrm{c}}^{\mathrm{HA}}$ の $C_{\mathrm{rr}}$ に対する変化を示す，図中には 参考のため, $C_{85} \operatorname{Ir}_{15}$ 合金ターゲットを用いて作製した薄 膜の磁化曲線も示した. $c$ 面配向化のためのシード層には, Coについては Ta(5 nm)/ Pt(6 nm)/ Ru(10 nm), 他の合金 組成については $\mathrm{Ta}(5 \mathrm{~nm}) / \mathrm{Pt}(6 \mathrm{~nm})$ を用いた. $H_{\mathrm{c}}{ }^{\mathrm{EA}}, H_{\mathrm{c}}{ }^{\mathrm{HA}}$ ともに, $C \mathrm{rr}$ を増加させるにつれて増加するものの, $C_{\mathrm{rr}}=18$ at.\%でもそれぞれ $28 \mathrm{Oe}, 20 \mathrm{Oe}$ 程度に抑えられることが わかった. このように CoIr 膜の軟磁性化には, 成膜時に誘 導される誘導磁気異方性の制御が重要である. 更なる軟磁 性化のためには, 粒径微細化によりナノクリスタル効果を 用いることが有効である ${ }^{15)}$. また $C_{\mathrm{Ir}}=18$ at. \%の試料では $K_{\mathrm{u}}$ grain は-7 $\times 10^{6} \mathrm{erg} / \mathrm{cm}^{3}$ 程度であることを別途確認して おり, CoIr 膜は, 大きな負の $K_{\mathrm{u}}$ grain と良好な膜面内方向の 軟磁気特性との両立が可能であることがわかった.

\section{WATE およびスパイクノイズ抑制効果}

最後に $c$ 面配向 CoIr 膜を SUL として用いた際の WATE およびスパイクノイズの抑制効果について評価した。 WATE の評価に用いた試料は SUL(120 T·nm)/ Ta(5 nm)/ $\mathrm{Pt}(6 \mathrm{~nm}) / \mathrm{Ru}(20 \mathrm{~nm}) / \mathrm{CoPtCr}-\mathrm{SiO}_{2}(10 \mathrm{~nm})$ なる層構成と した.ここで, WATE の測定は以下の手順で行った：まず 周波数 $133 \mathrm{kfci}$ の信号を 50 トラック記録し（記録電流 58 $\mathrm{mA}$ ), 微分信号のオフトラックプロファイル (OTP: Off-Track Profile) を測定し, 次に, センタートラックの みを $500 \mathrm{kfci}$ の信号で 10,000 回書き換え（記録電流 24 $\mathrm{mA})$, 最後に $133 \mathrm{kfci}$ の微分信号の OTP を測定した。今 回用いた WATE 評価試料では $24 \mathrm{~mA}$ の記録電流でも飽和 記録可能であることを確認した．Fig. 7 には，SULとして (a) アモルファス $\mathrm{Co}_{11} \mathrm{Zr}_{4} \mathrm{Nb}_{5}$ 膜を，（b） $c$ 面配向 $\mathrm{Co}_{82} \mathrm{Ir}_{18}$ 膜をそれぞれ用いた垂直二層膜媒体における，書き換え前 後の OTP を重ねて示した.（a)では，書き換え前の信号強 度（死色）と比較し書き換え後の信号強度（黒色）が著し く減衰しているのに対し，（b）では信号減衰が抑制されて いることがわかる. 尚, $c$ 面配向 CoIr 膜の WATE 抑制効 果の詳細については, 文献 8 にて議論している. 
スパイクノイズの評価試料の層構成は $\mathrm{Ta}(5 \mathrm{~nm}) / \mathrm{Pt}(6$ $\mathrm{nm}) / \mathrm{Co}{ }_{2} \operatorname{Ir}_{18} / \mathrm{Ta}(5 \mathrm{~nm}) / \mathrm{Pt}(6 \mathrm{~nm}) / \quad \mathrm{Ru}(20 \mathrm{~nm}) /$ $\mathrm{CoPtCr}-\mathrm{SiO}_{2}(10 \mathrm{~nm})$ とし, $\mathrm{CoIr}$ 層の実効膜厚 $\left(B_{\mathrm{s}} \cdot d_{\mathrm{CoIr}}\right)$ のタを変化させた. スパイクノイズは, 試料を DC 消磁し た後に，ディスク一周のエンベロープを測定することによ り評価した. Fig. 8 には, CoIr の実効膜厚を(a) $120 \mathrm{~T} \cdot n m$, (b) $80 \mathrm{~T} \cdot \mathrm{nm}$, (c) $60 \mathrm{~T} \cdot \mathrm{nm},(\mathrm{d}) 40 \mathrm{~T} \cdot \mathrm{nm}$ と変化させた際の,

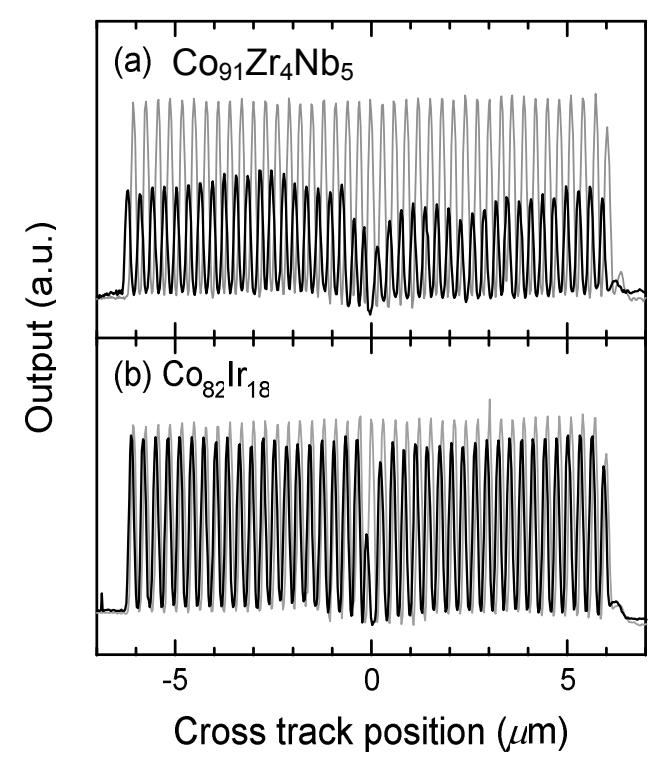

Fig. 7 Off-track profiles for perpendicular double-layered media using (a) CoZrNb film and (b) $c$-plane-oriented CoIr film as SUL, respectively. Gray and black lines denote initial signal power and signal power after rewriting center track, respectively

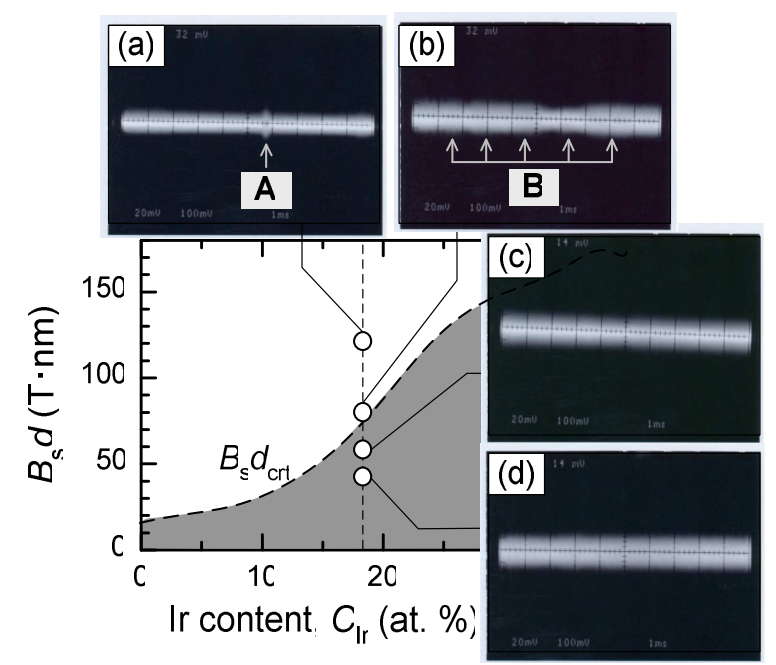

Fig. 8 Envelopes for perpendicular double-layered media using $c$-plane-oriented CoIr film as SUL. The Ir composition was fixed to 18 at.\%, and the effective thickness of CoIr was set to (a) 120, (b) 80, (c) 60, and (d) $40 \mathrm{~T} \cdot \mathrm{nm}$. "A" and "B" indicates the positions of observed spike noise. The effective critical thickness, $B_{\mathrm{s}} d_{\mathrm{crt}}$, calculated from the experimentally obtained $M_{\mathrm{s}}$ and $K_{\mathrm{u}}$ grain, is also shown.
エンベロープの評価結果を示す，図中には， $C$ r に対する CoIr 膜のネール磁壁安定化臨界実効膜厚 $\left(B_{\mathrm{s}} \cdot d_{\mathrm{crt}}\right)$ を $c$ 面 配向 CoIr 膜の $M_{\mathrm{s}}, K_{\mathrm{u}}$ grain の実験值を用いて計算した結果 も併せて示している．計算では $A$ を $1 \times 10^{-6} \mathrm{erg} / \mathrm{cm}$ と仮 定した．計算結果によると， $C_{\mathrm{rr}}=18$ at.\%の SULにおける $B_{\mathrm{s}} \cdot d_{\mathrm{crt}}$ は $76 \mathrm{~T} \cdot \mathrm{nm}$ と予想される. エンベロープの評価結果 を見てみると, (a), (b) では, 観測毎に発生位置が変化する スパイクノイズ (図中 $\mathrm{A}, \mathrm{B}$ 部) が明瞭に確認された。これ に対し実効膜厚が $76 \mathrm{~T} \cdot \mathrm{nm}$ よりも薄い (c)，(d)では，経時 変化するノイズ成分は観測されなかった。 今後磁壁内のス ピン構造を直接確かめる必要があるが，今回の結果は， $B_{\mathrm{s}} \cdot d_{\mathrm{crt}}$ 以下の膜厚設計によりネール磁壁を安定化させるこ とが，スパイクノイズの抑制効果をもたらすことを支持す るものである.

\section{5. まとめ}

簡素な層構成で WATE とスパイクノイズを同時抑制す るために, 一軸結晶磁気異方性エネルギー $\left(K_{\mathrm{u}}\right.$ grain $)$ が負で ある材料の $c$ 面配向化により, 負の垂直磁気異方性エネル ギー $\left(K_{\mathrm{u}}\right)$ を具備させた軟磁性裏打ち膜（SUL）を提案 した. 本 SUL では, 垂直方向の磁化率の低減および厚膜に おけるネール磁壁の安定化, 膜面内方向の磁気特性の軟磁 性化が期待される. 負の $K_{\mathrm{u}}$ grain を有する材料として hcp-CoIr 不規則相を選択し, 適切なシード層を用いて $c$ 面 配向膜を作製したところ, Ir 添加濃度 22 at. \%で $K_{\mathrm{u}}$ grain は極小值 $-6 \times 10^{6} \mathrm{erg} / \mathrm{cm}^{3}$ (飽和磁化 $M_{\mathrm{s}}=920 \mathrm{emu} / \mathrm{cm}^{3}$ ) を示すことがわかった。 $c$ 面配向 CoIr 膜を SUL として二 層膜媒体を作製したところ, 実用膜厚範囲で WATE ならび にスパイクノイズの抑制効果が確認された.

謝辞 結晶化ガラスディスク基板を御提供頂いた(株)才八 ラ R\&D センターの後藤直雪副参事に感謝致します.

\section{References}

1) S. Takahashi, K. Yamakawa, and K. Ouchi, J. Magn. Soc. Jpn., 23, Suppl. No. S2, 19 (1999).

2) K. Tanahashi, A. Kikukawa, N. Shimizu, and Y. Hosoe, J. Appl. Phys., 91, 8049 (2002).

3) S. Saito, K. Hirai, A. Hashimoto, M. Tsunoda, and M. Takahashi, J. Magn. Soc. Jpn., 27, 224 (2003).

4) B. R. Acharya, J. N. Zhou, M. Zheng, G. Choe, E. N. Abarra, and K. E. Johnson, IEEE Trans. Magn., 40, 2383 (2004).

5) K. Tanahashi, R. Arai, and Y. Hosoe, IEEE Trans. Magn., 41, 577 (2005).

6) A. Hashimoto, S. Saito, and M. Takahashi, J. Magn. Magn. Mat., 287, 287 (2005).

7) S. Iida, S. Iwasaki, Y. Iwama, H. Kobayashi, Y. Sakurai, T. Nagashima, and S. Watanabe: Jiseihakumakukougaku (in Japanese), p. 231 (Maruzen, 1977).

8) A. Hashimoto, S. Saito, and M. Takahshi, J. Appl. Phys., 99, (2006) in press. 
9) M. Takahashi, Y. Takahashi, and H. Shoji, IEEE Trans. Magn., 37, 2179 (2001).

10) M. Takahashi and S. Kadowaki, J. Phys. Soc. Jpn., 48, 1391 (1980).

11) T. Okita and Y. Makino, J. Phys. Soc. Jpn., 25, 120 (1968).

12) N. Kikuchi, O. Kitakami, S. Okamoto, Y. Shimada,A. Sakuma, Y. Otani, and K. Fukamichi J. Phys. Condens. Matter., 11, L485 (1999).

13) S. Saito, D. Hasegawa, F. Hoshi, D. D. Djayaprawira, and M. Takahashi, Appl. Phys. Lett., 80, 811 (2002).
14) T. Shimatsu, H. Sato, Y. Okazaki, O. Kitakami, S. Okamoto, H. Aoi, H. Muraoka, and Y. Nakamura, Digest of MMM 2005, DE-12.

15) M. Takahashi and T. Shimatsu; J. Magn. Magn. Mat., 101, 11 (1991).

2005年10月19日受理，2006年1月16日採録 